\title{
Pengembangan Media Pembelajaran Komik untuk Meningkatkan Hasil dan Minat Belajar Matematika Peserta Didik Kelas III SD Muhammadiyah Malawili
}

\author{
Ikhwatul Mujahadah $^{1}, \operatorname{Alman}^{2} \&$ Mukhlas Triono ${ }^{3}$
}

Program Studi PGSD, Universitas Pendidikan Muhammadiyah Sorong, Indonesia

E-mail: ikhwatul.mujahadah03@gmail.com

\begin{abstract}
Abstrak
Penelitian ini bertujuan untuk mengembangkan Media Komik sebagai media pembelajaran Matematika, meningkatkan hasil belajar Matematika, dan meningkatkan minat belajar peserta didik kelas III SD Muhammadiyah Malawili pada pembelajaran Matematika tahun ajaran 2019/2020. Penelitian ini menggunakan metode Design Research dengan mengacu pada model Thiagarajan atau dikenal dengan model 4-D, yang terdiri dari tahap define, design, develop, dan disseminate. Teknik pengambilan data pada penelitian ini menggunakan angket, lembar validasi, dan soal. Data yang diperoleh dari soal, angket, dan lembar validasi dianalisis secara kuantitatif lalu dikonversikan menjadi data deskriptif kualitatif. Hasil penelitian ini menunjukkan: media pembelajaran komik Matematika tahap pengembangan pada tahap ini penilaian kelayakan Media Pembelajaran memperoleh rata-rata skor 77,67 yang termasuk kategori sangat baik menunjukkan bahwa Media Pembelajaran Komik Matematika layak digunakan. Tahap Uji Keefektifan kepada 16 Peserta Didik Kelas III memperoleh persentase hasil belajar sebanyak $87,5 \%$ juga rata-rata skor nilai 80 dan Minat Belajar Matematika memperoleh interpretasi rata-rata sebanyak 33,56. Hal tersebut menunjukkan bahwa Media Pembelajaran Komik Matematika dapat digunakan untuk meningkatkan minat belajar Matematika maka kesimpulannya adalah Media Pembelajaran Komik Matematika dapat meningkatkan hasil dan minat belajar Matematika peserta didik kelas III SD Muhammadiyah Malawili.
\end{abstract}

Kata Kunci: Media Pembelajaran Komik; Hasil Belajar; Minat Belajar.

\begin{abstract}
This study aims to develop Comic Media as a Mathematics Learning Media, improve Mathematics Learning Outcomes, and increase the Learning Interest of Class III Students of SD Muhammadiyah Malawili in Mathematics Learning for the 2019/2020 Academic Year. This study used the Design Research method with reference to the Thiagarajan model or known as the 4-D model, which consists of the stages of define, design, develop, and disseminate. Data collection techniques in this study used questionnaires, validation sheets, and questions. The data obtained from questions, questionnaires, and validation sheets were analyzed quantitatively and then converted into qualitative descriptive data. The results of this study indicate: the learning media of Mathematics comics in the development stage at this stage the feasibility assessment of Learning Media obtained an average score of 77.67 which is included in the very good category, indicating that the Mathematics Comic Learning Media is feasible to use. The Effectiveness Test Phase for the 16 Class III Students obtained a percentage of learning outcomes as much as $87.5 \%$ also an average score of 80 and Mathematics Learning Interest obtained an average interpretation of 33.56. This shows that the Comic Mathematics Learning Media is suitable to be used to increase the interest in learning Mathematics, the conclusion is that the Mathematics Comic Learning Media can increase the results and interest in learning Mathematics for grade III students of SD Muhammadiyah Malawili.
\end{abstract}

Keywords: Comic Learning Media; Learning Outcomes; Learning Interest. 


\section{PENDAHULUAN}

Pendidikan diartikan sebagai sebagai usaha yang dilakukan pendidik sebagai upaya mengembangkan pengetahuan dan keterampilan bagi manusia. Pendidikan dibangun oleh beberapa komponen yaitu tujuan pendidikan, peserta didik, pendidik, kurikulum, bahan atau materi pelajaran, pendekatan, metode, media, sumber belajar dan evaluasi (Ratna, 2017). Dari komponen tersebut akan terbentuk suatu aktivitas pembelajaran yang ditandai dengan adanya interaksi peserta didik, pendidik, dan sumber belajar.

Pelajaran adalah salah satu pokok dalam proses pendidikan, beberapa mata pelajaran yang diajarkan di sekolah seperti Matematika. Pembelajaran Matematika yang terjadi di kelas kurang memberi kesempatan peserta didik untuk berpikir. Proses berpikir dalam matematika dapat memecahakan masalahhanya menghitung angka dan rumus, sehingga peserta didik dapat memahami dan mengaplikasikan dalam kehidupan seharihari. Ilmu Matematika selama ini yang tertanam dalam pikiran peserta didik adalah kebingungan dan kesulitan dalam menyelesaikan soal, hal ini dikarenakan Matematika yang sifatnya abstrak sehingga sulit diterima dalam benak peserta didik (Jailani. 2015).

Rasa jenuh dan bosan yang dirasakan peserta didik ini juga merupakan akibat dari pendidik yang kurang kreatif dalam proses pembelajaran sehingga minat belajar atau keinginan belajar peserta didik pun menjadi rendah, peseta didik cenderung tidak tertarik untuk belajar terutama pada pembelajaran Matematika. Seharusnya dalam mempelajari Matematika peserta didik harus memiliki keinginan yang tinggi untuk belajar sebab Matematika merupakan ilmu yang mengasah dan mengembangkan kemampuan berpikir dan menalar. Namun karena dalam proses pembelajaran kurang menarik mengakibatkan minat belajar peserta didik rendah (Sirait, 2016). Adapun indikator minat belajar meliputi pastisipasi dan ketertarikan belajar peserta didik ( Meilani, 2017)

Dari minat belajar peserta didik yang rendah mengakibatkan hasil belajar peserta didik tidak maksimal. Hasil belajar menjadi bukti keberhasilan dari proses pembelajaran peserta didik dengan dibuktikan hasil maksimum yang diperoleh setelah melakukan usaha-usaha belajar (Noor, 2015). Indikator hasil belajar dapat dinilai berdasarkan keterampilan dan tindakan peserta didik selama proses pembelajaran (Aan, 2016). Pembelajaran yang tidak menyenangkan tersebut sangatlah berpengaruh terhadap perkembangan peserta didik (Irma, 2016).

Dari data hasil ujian akhir semester mata pelajaran Matematika kelas III SD Muhammadiyah Malawili tahun 2019/2020 menunjukkan bahwa $60 \%$ dari 16 peserta didik kelas III masih dibawah Kriteria Ketuntasan Minimal (KKM=60).

Oleh karena itu diperlukan sesuatu yang menarik minat peserta didik untuk belajar sehingga hasil belajar Matematika bisa meningkat seperti media pembelajaran (Ambaryani, 2017). Media pembelajaran dapat menggambarkan materi Matematika yang abstrak. Penggunaan media pembelajaran diharapkan dapat membantu peserta didik menguasai materi yang diberikan (Witanta, 2019).

Penggunaan media pembelajaran yang efektif, inovatif dan kreatif juga diharapkan dapat meningkatkan hasil belajar peserta didik dan minat peserta didik, juga dapat merubah persepsi peserta didik mengenai Matematika yang sulit dan tidak menyenangkan (Nurita, 2018). Media 
pembelajaran sendiri memiliki jenis yang beraneka ragam seperti media visual, audio, dan audio visual (Rahma, 2019).

Adapun media yang paling mudah ditemukan oleh peserta didik tingkat sekolah dasar yakni media visual, selain itu media visual lebih banyak digunakan karena media visual lebih mudah dilihat dan diamati (Bahtiar, 2013), salah satu contoh media visual yang diajukan peneliti dalam penelitian ini yakni media pembelajaran komik.

Komik pada umumnya berisikan gambar, teks, dan cerita yang kemudian dicetak menjadi buku berukuran kecil (Jailani, 2015). Media komik ini akan memperjelas pikiran dan mempermudah dalam penyampaian informasi, hal ini karena komik mengandung unsur visual dan cerita yang kuat. (Siregar Rosliana, 2017).

Komik juga menggabungkan cerita dan unsur-unsur narasi yang mudah diterima oleh peserta didik baik yang dapat membaca maupun yang tidak dapat membaca dan menulis. Selain itu komik juga dapat mengembangkan kemampuan anak untuk membaca dan menulis (Budiarti,2016).

Dapat disimpulkan bahwa Media pembelajaran Komik Matematika adalah suatu alat atau media yang berisi cerita, dengan menggunakan rangkaian gambar tidak bergerak dalam bentuk frame kotak serta balon-balon ucapan dan simbol-simbol tertentu yang digunakan untuk menyampaikan pesan yang berisi permasalahan hitung matematika. Adapun kelebihan yang dimiliki media pembelajaran Komik Matematika antara lain : komik Matematika menciptakan minat peserta didik, membimbing dan menjembatani dalam menumbuhkan minat baca peserta didik, menambah kosa kata bagi pembacanya, mempermudah anak didik menangkap hal- hal yang bersifat abstrak, dan juga jalan cerita Komik Matematika memfokuskan pada satu hal kebaikan atau studi yang tengah dipelajari (Apriyanti, 2012).

Penelitian ini mengarah kepada hasil penelitian yang dilakukan oleh Dini Hidayanti yang berjudul "Pengembangan Komik Matematika Berbasis Edutainment untuk Memfasilitasi Pencapaian Pemahaman Konsep dan Motivasi Belajar Siswa SMP/MTS Kelas VIII pada Pokok Bahasan Lingkaran' Berdasarkan hasil penelitian presentase hasil belajar yang mendapatkan nilai besar sebanyak 65,62\% lebih besar dari sebelum menggunakan media, sedangkan rata-rata skor angket motivasi masuk ke dalam kategori baik (Dini Hidayanti, 2015).

Penelitian yang relevan selanjutnya dilakukan oleh Dewi Nafisah Huda yang berjudul "Pengembangan Media Pembelajaran Menggunakan Android - Based Game untuk Meningkatkan Minat dan Hasil Belajar Peserta Didik SMA Kelas X SMA Negeri 2 Bantul". Berdasarkan hasil penelitian tersebut peserta didik mengalami peningkatan hasil belajar dan minat belajar setelah menggunakan media tersebut (Dewi Nafisah Huda, 2018).

Persamaan penelitian oleh Dini Hidayanti dengan penelitian yang akan dilakukan adalah sama-sama menggunakan media pembelajaran Komik Matematika sedangkan penelitian oleh Dewi Nafisah Huda sama-sama menggunakan media untuk meningkatkan hasil dan minat belajar peserta didik.

Perbedaannya penelitian oleh Dini Hidayanti menggunakan media Komik Matematika dilakukan pada tingkat sekolah menengah pertama. Sedangkan penelitian yang akan dilakukan berfokus pada tingkat sekolah dasar. Sedangkan Dewi Nafisah Huda tidak menggunakan Komik sebagai 
media pembelajarannya melainkan menggunakan Android-Based Game, sedangkan penelitian yang akan dilakukan menggunakan media Komik.

Media pembelajaran ini dikembangkan untuk menghasilkan media pembelajaran Komik Matematika yang valid, efektif, dan praktis. Sehingga dapat tercipta proses pembelajaran yang efektif.

\section{METODE PENELITIAN}

Penelitian ini menggunakan metode Design Research yaitu metodologi yang berfokus pada perancangan, mengembangkan, dan mengevaluasi upaya yang dilakukan untuk meningkatkan pendidikan. Barab dan Squire (2004) mendefinisikan penelitian berbasis desain sebagai "serangkaian pendekatan, dengan tujuan menghasilkan teori, artefak, dan praktik yang memperhitungkan dan berpotensi memengaruhi pembelajaran dan pengajaran dalam pengaturan naturalistik (Herrington, J., McKenney, S. Reeves, T.C., \& Oliver, R, 2007). Proses penelitian pada design research meliputi langkah-langkah seperti halnya proses perancangan pendidikan (educational design), yaitu analisis, perancangan, evaluasi dan revisi. Adapun dalam penelitian ini peneliti menggunakan design research model Reeves 2006 (Lidinillah, 2012).

Penelitian ini mengacu pada model Thiagarajan atau dikenal dengan model 4-D, yang terdiri dari tahap pendefinisian (define), perancangan (design), pengembangan (develop), dan penyebaran (disseminate). Penelitian dilaksanakan pada 22-25 Juni 2020 di kelas III SD Muhammadiyah Malawili dan subjek penelitian ini adalah peserta didik kelas III SD Muhammadiyah Malawili dengan jumlah 16 peserta didik.

Pada tahap pengembangan Media
Pembelajaran Komik Matematika dinilai kelayakannya sebagai media pembelajaran oleh 1 Ahli Materi, 1 Ahli Media, 2 Responden Uji Kepraktisan, dan melakukan uji coba berupa tes dan minat ke peserta didik kelas 3. Teknik pengambilan data pada penelitian ini menggunakan angket, lembar validasi, dan soal pre-test dan post-test.

Dalam penelitian ini data dianalisa guna memperoleh media pembelajaran yang layak digunakan dan bernilai minimal valid atau baik. Data berupa skor yang diperoleh dari soal, angket, dan lembar validasi dari para ahli dan responden, skor penilaian dari para ahli dan responden kemudian dikonversikan data kuantitatif tersebut menjadi data kualitatif. Skor yang diperoleh menjadi nilai pada skala 5 , dengan mengacu pada tabel 1 berikut ini.

Tabel 1. Konversi Data Kuantitatif Menjadi Data Kualitatif

\begin{tabular}{ccc}
$\begin{array}{c}\text { Data } \\
\text { Kuantitatif }\end{array}$ & Skala/Rentang & $\begin{array}{c}\text { Data } \\
\text { Kualitatif }\end{array}$ \\
\hline 5 & $\mathrm{X}>\mathrm{Xi}+1,50 \mathrm{SBi}$ & $\begin{array}{c}\text { Baik } \\
\text { Sekali }\end{array}$ \\
4 & $\mathrm{Xi}+0,50 \mathrm{SBi}<\mathrm{X}$ & Baik \\
& $\leq \mathrm{Xi}+1,50 \mathrm{SBi}$ & \\
& $\mathrm{Xi}-0,50 \mathrm{SBi}<\mathrm{X} \leq$ & Cukup \\
3 & $\mathrm{Xi}+0,50 \mathrm{SBi}$ & Baik \\
& $\mathrm{Xi}-1,50 \mathrm{SBi}<\mathrm{X} \leq$ & Kurang \\
2 & $\mathrm{Xi}-0,50 \mathrm{SBi}$ & Baik \\
& $\mathrm{X} \leq \mathrm{Xi}-1,50 \mathrm{SBi}$ & Tidak \\
& & Baik \\
\hline
\end{tabular}

Keterangan :

$\mathrm{Xi}=$ Rata-rata ideal

$=1 / 2($ skor tertinggi + skor terendan $)$

$\mathrm{SBi}=$ Standar deviasi ideal

$=1 / 6$ (skor tertinggi - skor terendah)

$\mathrm{X}=$ Skor penilaian dari para ahli

(Triono M, 2019)

Apabila dalam penelitian seluruh aspek bernilai sangat setuju dan juga setuju maka media dari hasil pengembangan dinyatakan berkualitas dan praktis untuk digunakan. 
Selanjutnya dilakukan uji keefektifan untuk melihat hasil belajar dan minat belajar. Untuk data hasil tes, digunakan nilai kriteria ketuntasan minimal (KKM) yang telah ditetapkan oleh sekolah yaitu 60 untuk mata pelajaran Matematika, apabila $80 \%$ dari peserta didik telah mencapai nilai KKM yaitu 60, itu berarti produk media pembelajaran komik telah efektif untuk digunakan.

\section{HASIL DAN PEMBAHASAN}

Penelitian ini menghasilkan produk berupa media komik Matematika untuk kelas III semester 2 SD pada materi satuan waktu. Pengembangan ini dilakukan dengan model 4-D sebagai berikut.

\section{Tahap Pendefinisian}

\section{Analisis Awal Akhir}

Analisis ini dilakukan dengan tujuan mencari tau mengenai permasalahan yang dialami sekolah, adapun permasalahan yang ditemui antara lain: Banyak nilai yang tidak mencapai nilai KKM dan pendidik yang terpaku hanya pada buku cetak yang menyebabkan peserta didik menjadi mudah jenuh dan bosan.

\section{Analisis Peserta Didik}

Pada tahap ini akan dilihat kemampuan belajar anak sampai mana dengan menggunakan soal tes

\section{Analisis Tugas}

Dalam tahap ini perumusan materi, kompetensi dasar, dan indikator pembelajaran dilakukan yang kemudian dijadikan acuan untuk pembuatan media pembelajaran.

\section{Analisis Konsep}

Pada proses ini peneliti mengumpulkan sumber-sumber yang akan mendukung dalam proses pengembangan media pembelajaran.

\section{Spesifikasi Tujuan Pembelajaran}

Perumusan tujuan pembelajaran dibuat dengan mengacu pada kompetensi dasar yang telah tercantum dalam buku pembelajaran yang digunakan peserta didik dan pendidik.

Tahap Desain, Pada tahap ini dihasilkan perangkat pembelajaran berupa instrumen pembelajaran dan media pembelajaran yang akan digunakan sebagai bahan penelitian. Tahap ini dilakukan dengan beberapa langkah atau proses; Penyusunan Perangkat Penelitian

Proses ini dilakukannya penyususnan RPP (Rancangan Pelaksanaan Pembelajaran), angket minat, dan soal test untuk peserta didik. Pemilihan Media Menentukkan materi yang akan dimasukkan ke dalam komik dan merencanakan bentuk media Pemilihan Format. Mendesain isi dari media pembelajaran Komik Matematika sehingga memenuhi kriteria yang menarik, memudahkan dan membantu proses pembelajaran.

\section{Tahap Pengembangan}

Rancangan Awal Pada tahap ini mulai merancang media pembelajaran komik dengan bantuan aplikasi bawaan dari PC/Laptop.

Validasi Ahli Media, Setelah produk berhasil dibuat maka dilakukan validasi. Dalam validasi ini, peneliti, mendapatkan skor sebanyak 46, hal ini menunjukkan media masuk kategori baik sekali apabila dilihat dari tabel klasifikasi interpretasi berikut:

Tabel 2. Tabel Klasifikasi Interpretasi Validasi Ahli Media

\begin{tabular}{cc}
\hline Skala Skor & Klasifikasi \\
\hline $\mathrm{X}>45,5$ & Baik Sekali \\
$38,5<\mathrm{X} \leq 45,5$ & Baik \\
$31,5<\mathrm{X} \leq 38,5$ & Cukup Baik \\
$24,5<\mathrm{X} \leq 31,5$ & Kurang Baik \\
$\mathrm{X} \leq 24,5$ & Tidak Baik \\
\hline
\end{tabular}

\section{Uji Coba Pengembangan}

Uji coba ini terdiri dari uji kepraktisan dan uji keefektifan

\section{Uji Kepraktisan}


Uji ini dilakukan untuk mengetahui tingkat kemudahan dan keterlaksanaan suatu produk sudah baik atau belum. Dalam uji kepraktisan ini media Komik Matematika mendapatkan skor sebanyak 70 dari responden 1 dan 79 dari responden 2. Berdasarkan tabel klasifikasi interpretasi media komik mendapat nilai kepraktisan baik sekali. Tabel klasifikasi interpretasi dapat dilihat sebagi berikut:

Tabel 3. Klasifikasi Interpretasi Uji Kepraktisan

\begin{tabular}{cc}
\hline Skala Skor & Klasifikasi \\
\hline$X>65$ & Baik Sekali \\
$55<X \leq 65$ & Baik \\
$45<X \leq 55$ & Cukup Baik \\
$35<X \leq 45$ & Kurang Baik \\
$X \leq 35$ & Tidak Baik \\
\hline
\end{tabular}

\section{Uji Keefektifan}

Uji keefektifan merupakan uji yang dilakukan untuk melihat keberhasilan suatu media dengan diukur berdasarkan kualitas dan kuantitas sehinggamenghasilkan luaran yang diharapkan. Pada uji ini peserta didik diberikan soal post-test untuk mengetahui peningkatan hasil belajar yang didapat peserta didik setelah menggunakan media Komik Matematika. Data hasil tes pada uji ini dapat dilihat pada tabel 5 berikut ini:

Tabel 4. Rata-rata Pre-test dan Post test SD Muhammadiyah Malawili

\begin{tabular}{cc}
\hline Perlakuan & Rata-Rata Skor \\
\hline Pretest & 54,68 \\
Posttest & 80 \\
Beda & 25,32 \\
\hline
\end{tabular}

Dalam penelitian ini menunjukkan hasil belajar mengalami peningkatan dari rata-rata 54,68 sebelum menggunakan komik, dan rata-rata 80 setelah menggunakan komik menunjukkan perbedaan sebanyak 25,32, hal tersebut menunjukkan bahwa ratarata nilai peserta didik sudah melewati KKM (Kriteria Ketuntasan Minimal), dan juga dari perhitungan presentase hasil belajar secara keseluruhan menunjukkan hasil belajar peserta didik mengalami peningkatan sebanyak 56,25\% ,dari total 31,25\% sebelum menggunakan media Komik Matematika menjadi $87,5 \%$ setelah menggunakan media Komik Matematika.

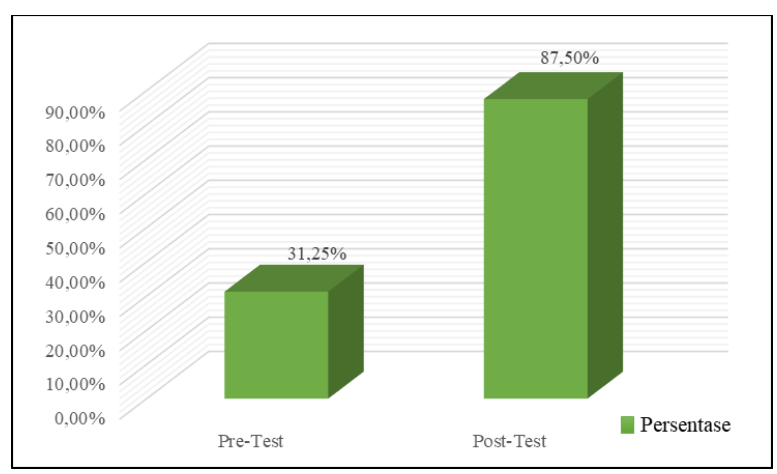

Gambar 1. Diagram Perbandingan Persentase Hasil Belajar

\section{Angket Minat Peserta Didik}

Secara klasikal skor minat setelah menggunakan media mendapatkan skor ratarata sebanyak 33,56 hal ini menunjukkan bahwa minat anak belajar matematika setelah menggunakan media Komik Matematika "Baik Sekali", padahal sebelum menggunakan media Komik Matematika minat anak belajar Matematika hanya mendapatkan skor rata-rata sebanyak 19 masuk ke dalam kategori "Kurang Baik". Hal tersebut menunjukkan peningkatan sebanyak 14,56 skor dari sebelum menggunakan media sampai setelah menggunakan media.

Tabel 5. Klasifikasi Interpretasi Validasi Materi dan Minat

\begin{tabular}{cc}
\hline Skala Skor & Klasifikasi \\
\hline$X>32,5$ & Baik Sekali \\
$27,5<X \leq 32,5$ & Baik \\
$22,5<X \leq 27,5$ & Cukup Baik \\
$17,5<X \leq 22,5$ & Kurang Baik \\
$X \leq 17,5$ & Tidak Baik \\
\hline
\end{tabular}

\section{Tahap Diseminasi}

Tahapan ini dilakukan setelah 
dilakukan uji pengembangan, pada tahap ini akan dilakukan penyebaran dan penerapan aplikasi pembelajaran di SD Muhammadiyah Malawili khususnya kelas III. Dilakukan setelah penelitian.

Hasil penelitian menunjukkan bahwa media komik pembelajaran berpengaruh positif terhadap hasil belajar dan minat belajar peserta didik dalam pembelajaran Matematika. Dari penelitian ini juga, peneliti memperoleh media pembelajaran komik yang memenuhi kriteria efektif, inovatif, dan kreatif

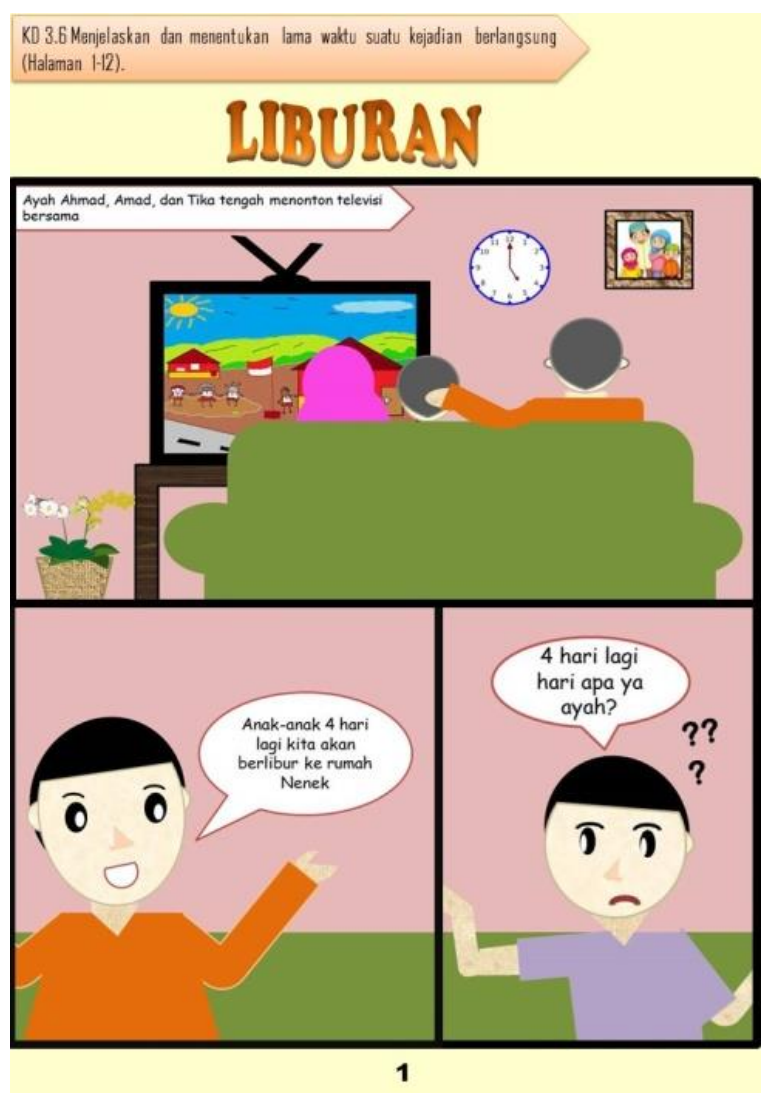

Gambar 2. Tampilan Komik yang Telah Dirancang

Media ini dibuat semenarik mungkin, mudah dipahami, dan mudah digunakan dimana saja, kapan saja, dan oleh siapa saja. Susunan komik yang berhasil dirancang terdiri dari halaman pembuka komik, isi komik, bagian/chapter tambahan, dan halaman penutup.

\section{KESIMPULAN}

Berdasarkan hasil pengamatan dan analisis terhadap hasil penelitian, maka dapat diambil kesimpulan bahwa Media pembelajaran Komik Matematika yang dikembangkan untuk pembelajaran Matematika layak digunakan. Hal ini ditinjau dari hasil penilaian dari aspek media sebanyak 46 dan aspek materi sebanyak 38 menunjukkan kriteria baik sekali. Presentase hasil belajar secara keseluruhan mengalami peningkatan sebanyak $56,25 \%$,dari total $31,25 \%$ sebelum menggunakan media Komik Matematika menjadi $87,5 \%$ setelah menggunakan media Komik Matematika. Minat belajar juga memperoleh interprestasi rata-rata dari seluruh total responden sebanyak 33,56 yang tergolong "Baik Sekali"

\section{DAFTAR RUJUKAN}

Aan, L. (2016). Peningkatan Hasil Belajar Matematika Siswa Melalui Model Kooperatif Teknik Think Pair Share (TPS) Penelitian Tindakan Kelas Terhadap Siswa Kelas VII-A SMPN Sukasari Sumedang. Jurnal Pendidikan, II(3 September 2016), 18-26.

Ambaryani, A. S. G. (2017). Pengembangan Media Komik Untuk Efektivitas Dan Meningkatkan Hasil Belajar Kognitif Materi Perubahan Lingkungan Fisik. Jurnal Pendidikan, 3(1), 19-28.

Apriyanti F. (2012). Pengaruh Pemanfaatan Media Komik Matematika Terhadap Hasil Belajar Kelas V SDN 24 Pontianak Tenggara. Pontianak: Universitas Tanjungpura.

Budiarti, W., \& Haryanto, H (2016). Pengembangan Media Komik untuk Meningkatkan Motivasi Belajar dan Keterampilan Membaca Pemahaman Siswa Kelas IV. Jurnal Prima Edukasia, 4(2), 233242.

Herrington, J., McKenney, S. Reeves, T.C., \& Oliver, R. (2007). Design-based research and doctoral students: Guidelines for preparing a dissertation proposal. Proceedings of World Conference on Educational Multimedia, Hypermedia 
and Telecommunications (pp. 4089-4097). Chesapeake, VA: AACE.

Hidayanti D. (2015). Pengembangan Komik Matematika Berbasis Edutainment untuk Memfasilitasi Pencapaian Pemahaman Konsep dan Motivasi Belajar Siswa SMP/MTS Kelas VIII pada Pokok Bahasan Lingkaran. Yogyakarta: Universitas Islam Negeri Sunan Kalijaga.

Huda N, Astono J. (2018). Pengembangan Media Pembelajaran Menggunakan Android-Based Game untuk Meningkatkan Minat dan Hasil Belajar Peserta Didik SMA Kelas X SMA Negeri 2 Bantul. Jurnal Pendidikan Fisika. 7(1): 61-73.

Irma, A. (2016). Meningkatkan Aktivitas Dan Hasil Belajar Matematika Menggunakan Model Pembelajaran Kooperatif Tipe Group Investigation Di SMK Tuma'Ninah Yasin Metro. Jurnal SAP, 1(2), 105-114.

Jailani, I. (2015). Pengembangan Media Komik Pembelajaran Matematika Meningkatkan Motivasi Dan Prestasi Belajar Siswa Kelas V Developing. Jurnal Prima Edukasia, 3(1), 84-96.

Lidinillah M.A.D. (2012). Design Research sebagai Model Penelitian Pendidikan. Artikel Kepenulisan Skripsi. Universitas Pendidikan Indonesia Kampus Tasikmalaya.

Meilani, R. I. (2017). Impak minat dan motivasi belajar terhadap hasil belajar siswa (The impacts of students 'learning interest and motivation on their learning outcomes). Jurnal Pendidikan, 2(2), 188-201.

Noor, P. K. (2015). Pengaruh Tingkat Pendidikan, Perhatian Orang Tua, Dan Minat Belajar Siswa Terhadap Prestasi Belajar Bahasa Indonesia Siswa SMK
Kesehatan Di Kota Tanggerang. Jurnal Pujangga Bahasa dan Sastra, 1(2), 75105.

Nurrita T. (2018). Pengembangan Media Pembelajaran untuk Meningkatkan Hasil Belajar Siswa. Misykat, 03(01), 171-187.

Rahma, I.F. (2019). Media Pembelajaran (kajian terhadap Langkah-langkah Pemilihan Media dan Implementasinya dalam Pembelajaran bagi Anak Sekolah Dasar). Jurnal Studi Islam. 14(2).

Ratnasari, I. W. (2017). Hubungan Minat Belajar Terhadap Prestasi. Jurnal Psikoborneo, 5(2), 400-405.

Sirait, E. D. (2016). Pengaruh Minat Belajar Terhadap Prestasi. Jurnal Pendidikan, 6(1), 35-43.

Siregar Rosliana, S. A. P. (2017). Pengaruh Penggunaan Media Komik Matematika Dengan Bantuan Power Point Terhadap Motivasi dan Hasil Belajar Matematika Siswa Di SMK Istiqlal Delitua. Journal Mathematics and Science, 3(1), 91-100.

Supriyono \& Bahtiar R.S. (2013). Penggunaan Media Visual untuk Meningkatkan Hasil Belajar pada Tema Lingkungan Siswa Kelas II Sekolah Dasar. Jurnal PGSD. 1(2).

Triono M, Retnowati, E. (2019). Validity assessment of a multimedia based on cognitive load theory for undergraduate plane geometry learning Validity assessment of a multimedia based on cognitive load theory for undergraduate plane geometry learning. https://doi.org/10.1088/17426596/1320/1/012084

Witanta V.A, Baiduri, Inganah S. (2019). Pengembangan Komik Sebagai Media Pembelajaran Matematika Pada Materi Perbandingan Kelas VII SMP. Jurnal Ilmiah Pendidikan Matematika.1(1), 